\title{
Stumbling Towards War: The Soviet Decision To Invade Afghanistan
}

Matt W. Wolf, University of Alberta

\section{Introduction}

The Soviet Union's 1979 invasion of Afghanistan definitely serves as a major milestone in the demise of the Soviet Empire. Prior to the invasion, Soviet fortunes in the world seemed to be improving consistently: Moscow had engaged in a series of proxy wars throughout the Third World during the 1970s. At the same time, direct tensions between the USSR and the United States relaxed dramatically under the policy of détente. Despite slowing economic growth, the Soviet economy could still earn hard currency through the sale of commodities abroad. Yet the 1979 invasion would shatter the myths of the Soviet Union. Gone was the image of a 'peace loving' Moscow that merely wanted to coexist. Afghanistan significantly helped the West in uniting against the Soviet Union. In the eyes of the Soviet people, the war would discredit four General Secretaries. Afghanistan exposed the Soviet military's feet of clay. Heavy casualties among the Baltic Soviet republics, who were overly represented in the theatre, would contribute to the rise of nationalism. In retrospect, it is striking to see how truly catastrophic the decision to invade a backward and seemingly insignificant country was to the fate of the Soviet Union. ${ }^{1}$

Yet what were the Soviet Union's initial motivations for invading? Were they indeed acting on a grand strategy that sought

\footnotetext{
${ }^{1}$ For a greater explanation of the true cost of the invasion on the Soviet Union, see Anthony Arnold, The Fateful Pebble: The Soviet Invasion in Perspective (Novato, CA: Presidio Press, 1993). 
to encroach on the Middle East? On the other hand, was the Soviet Union merely acting to help their fellow comrades whose revolution was struggling? In the end, it would be the fear of 'losing' Afghanistan that would provide the greater motivation for becoming involved in a state of little to no strategic value in the first place. As the situation in Afghanistan continually worsened, 2) the Soviet leadership, specifically the faction centered on KGB Chairman Yuri Andropov, began to 'worst case' every scenario.

\section{Soviet-Afghan Relations before 1979}

While relations between the Soviet Union and Afghanistan were nearly as old as the Bolshevik revolution itself, a true relationship built upon international socialism did not emerge until the 1960s. Prior to the establishment of the Afghan Communist Party, dubbed the People's Democratic Party of Afghanistan (PDPA), relations between Moscow and Kabul were largely based upon economic linkages, and minor ones at that. Yet the establishment of the PDPA, in 1965 - with ample encouragement from Moscow - saw the development of a formal institutional linkage between Afghan communists and Moscow. However, the PDPA would quickly splinter into numerous factions, the two most prominent being the Khalq and the Parcham. It was the Khalq, whose base was initially composed of intellectuals, media personnel, and teachers, which would rise to power following the violent overthrow of President Daud in late April 1978. ${ }^{2}$ While there was an alliance formed between the Khalq and the Parcham shortly prior to the coup, this quickly deteriorated into fierce and violent inter-PDPA fighting

\footnotetext{
${ }^{2}$ Anthony Arnold, The Fateful Pebble: The Soviet Invasion in Perspective (Novato, CA: Presidio Press, 1993), 44, 56.

Past Imperfect 12 [2006]| (C) |ISSN 1192-1315
} 
within months of the 1978 'Revolution.' The Khalq, which had become increasingly prominent within the Afghan military and police, would emerge as the stronger faction, with senior Parchamani leaders being 'promoted' to ambassadorial posts aboard. As far as Moscow was concerned, the Khalq should have been firmly in control in Afghanistan.

After consolidating power within the PDPA, the Khalq faction quickly began numerous reforms, most of which proved to be widely unpopular among the general population which had not previously experienced a strong central government. In particular, the Khalq initiated doctrinaire land reforms, which contravened the well-established tribal land system of Afghanistan. Khalq leaders viewed Islam as an abomination and aimed to remove its influence from Afghan society, further alienating the devout population. ${ }^{3}$ PDPA General Secretary Nur Mohammad Taraki had extensively studied the initial aftermath of the Bolshevik revolution, and had become convinced that a period of 'Red Terror' was required for Afghanistan's progression first to socialism and then to communism. ${ }^{4}$ As such, the Khalq proceeded with their "suicidal program of forced-draft Sovietization of Afghan society" in a country that has historically seen very little centralized governmental control. ${ }^{5}$ Due to these brutal reforms, the Afghan countryside had quickly deteriorated into a state of de facto civil war in late 1978.

\footnotetext{
${ }^{3}$ Henry S. Bradsher, Afghan Communism and Soviet Intervention (Oxford: Oxford University Press, 1999), 41-43.

${ }^{4}$ Christopher Andre and Vasili Mitrokhin, The Mitrokhin Archive II: The KGB in the World (London: Allen Lane, 2005), 389.

${ }^{5}$ Arnold, The Fateful Pebble, 97. 


\section{Decision-making with the Soviet Leadership, January- August 1979}

While the situation in Afghanistan had become increasingly tumultuous upon the PDPA's coming to power in 1978, the view the Soviet leadership held in early 1979 is highly surprising considering 4| the eventual path the Soviet leadership would ultimately choose in late 1979. The official records of the period reflect a near unanimous view that direct military intervention in Afghanistan was not in the interests of the Soviet Union. This was the view stated by all members of the Politburo during the period. Premier Alexey Kosygin seemingly played the dominant role in the meetings, saying that direct intervention would "alarm the international community" and would invite "sharply unfavorable multi-pronged consequences" for the Soviet Union. ${ }^{6}$ Foreign Minister Andrei Gromyko expressed a fear that in being greeted as an aggressor, the Soviet Union would be handing China a gift. At this point, KGB Chairman Yuri Andropov was wholly opposed to intervention, regarding it as "entirely inadmissible" that Soviet troops would be forwarding the Afghan revolution with the "aid of a bayonet." A similar position was held by Defense Minister Dmitrii Ustinov. ${ }^{7}$

When one reviews the Politburo meetings in question, groupthink, in which members conform to one opinion to one

\footnotetext{
${ }^{6}$ Transcript: Politburo meeting, March 20, 1979. Reproduced and translated in Documents on the Soviet Invasion of Afghanistan. E-Dossier No. 4. Cold War International History Project. Woodrow Wilson International Center for Scholars, Washington, D.C. November 2001. 131-32. http://wilsoncenter.org/topics/pubs/edossier 4.pdf. Hereafter 'E-Dossier No. 4. Andropov quoted on 72.

${ }^{7}$ Transcript: Politburo meeting, March 17, 1979: "About the Exacerbation of the Situation in the Democratic Republic of Afghanistan and Our Possible Moves." EDossier No. $4,70$.
} 
viewpoint, seems to be at play within the meetings themselves: there is no major dissent present and virtually no differing opinions during early 1979. Nevertheless, the official records are the best source that can be provided at this current date.

Ironically, if there was one group that consistently promoted the introduction of Soviet troops into Afghanistan throughout this period, it was the Afghan leadership itself. As the situation worsened, the PDPA became increasingly concerned about the possibility of mutinies and active revolts occurring within the Afghan army itself, and as such, the armed forces suffered continual purges. Thus, despite the massive amount of training and armaments provided by the Soviet Union, the Afghan army could provide no means of assurance for the Afghan government. Despite Moscow's best efforts to develop a self-supporting regime in Afghanistan, Kabul became increasingly more dependent on Moscow as time progressed. ${ }^{8}$

During a March telephone conversation between Premier Kosygin and Afghan Prime Minister Taraki, the latter requested the deployment of Uzbek, Tajik, and Turkmen Red Army regulars to operate the tanks and armored vehicles Moscow had previously supplied. ${ }^{9}$ Taraki would also become increasingly persistent that Soviet pilots be provided to man newly acquired Mi-24 'Hind' helicopter gunships. This request was continually and unequivocally quashed by both Defense Minister Ustinov and Army Chief of Staff Marshal Nikolai Ogarkov. Nevertheless, the Afghan government continued to request Soviet pilots up until the

\footnotetext{
${ }^{8}$ Milton F. Goldman, "Soviet Military Intervention in Afghanistan: Roots and Causes," Polity 16, no. 3 (Spring 1984), 400-401.

9 Transcript of telephone conversation between Soviet Premier Kosygin and Afghan Prime Minister Taraki. 17 or 18 March 1979. E-Dossier No. 4, 146.

Past Imperfect 12 [2006]| (C) |ISSN 1192-1315
} 
invasion itself. ${ }^{10}$ Upon returning from a fact-finding mission to Afghanistan, Politburo member Boris Ponomarev forwarded a request from the PDPA for the deployment of two Soviet divisions into Afghanistan for use in "emergency circumstances."11 Today it remains unclear who within the PDPA actually requested this deployment, which was subsequently denied. Perhaps most 6| theatrically, both Taraki and Hafizullah Amin, Taraki's deputy and future short-term successor, had suggested that occupying Afghanistan would serve as an excellent steppingstone for a great Soviet move to achieve the Strait of Hormuz. ${ }^{12}$ What continues to be clear is that if Moscow had intended to occupy Afghanistan as part of some sort of 'grand strategy,' they clearly had ample opportunity to do so with the blessings of the Afghan government throughout the summer of 1979. However, Moscow consistently chose not to intervene directly, to the dismay of the PDPA leadership.

In addition to continual requests for a direct Soviet intervention, the PDPA leadership also advanced an excessive view of foreign interference within Afghan affairs. The Afghan government consistently exaggerated Iran's involvement in Afghan unrest, at times stating that the revolts were led by Iranian infiltrators that entered the country with deported Afghans. An April Politburo memorandum stated that Iran was the "underlying cause of the activation of the struggle against the government in

\footnotetext{
${ }^{10}$ Report of the Chief of the Soviet Military Advisory Group in Afghanistan, Lt. Gen. L.N. Gorelev. 14 April 1979. E-Dossier No. 4, 151.

${ }^{11}$ Vasili Mitrokhin, The KGB in Afghanistan. Working Paper No. 40. Introduced and edited by Christian F. Ostermann and Odd Arne Westad. Cold War International History Project. Woodrow Wilson International Center for Scholars, Washington, D.C. Feb. 2002. http://wilsoncenter.org/topics/pubs/ACFAE9.pdf. 111.

${ }^{12}$ Ibid. 
Afghanistan. ${ }^{13}$ While revolutionary Iran undoubtedly played a role in riots among the Shiites in western Afghanistan, of which there were relatively few, this does not account for unrest in the remainder of the countryside. ${ }^{14}$ At other times, Pakistan was accused of controlling the rebellions. Again, there were elements of truth to these accusations, yet Pakistan's involvement was widely overstated. In conjunction, the PDPA attempted to convince Moscow that both the Americans and Chinese were arming the rebels and "persistently pushing the Pakistanis against us." ${ }^{15}$ In his memoirs, former CIA Director Robert Gates notes that the US did begin outreach programs with Afghan resistance leaders on July 3, 1979. ${ }^{16}$ However, it was not until Moscow crossed the threshold that Washington, in conjunction with Pakistan and China, began major coordinated operations to fuel the insurgency. ${ }^{17}$ The Afghan leadership was undoubtedly trying to stoke Moscow's greater geopolitical fears to their own benefit. In reality, there were more than enough Soviet-made arms being provided to the rebels by soldiers who had deserted. ${ }^{18}$ While the PDPA was unsuccessful at convincing Moscow to directly intervene in spring 1979, they were largely successful at convincing the Soviet leadership that their civil war was in fact a campaign fueled by external counter-revolutionary forces, rather than a domestic

\footnotetext{
${ }^{13}$ Memorandum of Protocol no, 149 of the meeting of the Politburo (CC CPSU). 12 April 1979. E-Dossier No. 4, 68.

${ }^{14}$ Transcript: Telephone conversation between Soviet Premier Kosygin and Afghan Prime Minister Taraki, 17 or 18 March 1979. E-Dossier No. 4, 145.

${ }_{15}$ Transcript: Meeting of A.N. Kosygin, A.A. Gromyko, D.F. Ustinov and B.N. Ponomarev with N.M. Taraki. 20 March 1979. E-Dossier No. 4, 73.

${ }^{16}$ Robert M. Gates, From the Shadows: The Ultimate Insider's Story of Five Presidents and How they Won the Cold War (New York: Simon and Schuster, 1996), 146.

${ }^{17}$ Steve Coll, Ghost Wars (New York: Penguin, 2004), 67-83.

${ }^{18}$ Andrew, The Mitrokhin Archive II, 379. 
uprising sparked by the PDPA's own brutal attempts at exerting centralized control.

Within the Soviet archives, it is consistently noted that it was the Soviet Union's duty to help their Afghan comrades, and that the failure of an Afghan socialist state would not be in the interests of the Soviet Union. However, the view that the direct use

8| of Soviet power in Afghanistan was not an option was prominent well through the summer and into the fall, with modest dissents emerging only in September 1979. It should be noted that it was during this period that there was a large-scale uprising in the Western city of Herat. By December, the uprising had been crushed, and the situation in Afghanistan as a whole was arguably more stable than in March, yet the decision to invade was nevertheless made. $^{19}$ What had transpired during this period that led the Politburo to reverse their earlier - now seemingly wiser decisions?

\section{Decision-making within the Soviet Leadership, September-December 1979}

Since the People's Democratic Party of Afghanistan's (PDPA) earliest days, Moscow had always viewed the divided nature of the Party as perilously detrimental to the development of Afghan communism: it was under Moscow's guidance that an alliance was formed between the warring factions prior to the 1978 coup. Yet entering 1979, a power struggle within the ruling Khalq faction had emerged between General Secretary Taraki and his deputy,

\footnotetext{
${ }^{19}$ M. Hassan Kakar, Afghanistan: The Soviet Invasion and the Afghan Response, 1979-1982 (Berkeley, CA: University of California Press, 1995), 47.

Past Imperfect 12 [2006] | (C) ISSN 1192-1315
} 
Hafizullah Amin. ${ }^{20}$ This division was indeed detrimental to the stability of the country. Perhaps more importantly, it seriously distorted the view the Moscow leadership had of the situation in Afghanistan throughout 1979.

Despite Taraki's insistence that a period of terror was necessary to pacify Afghanistan, he was viewed as the moderate leader of the Khalq within the Soviet foreign policy establishment. Amin, who would first become foreign minister and later premier in March 1979, was seen as far more divisive within the Afghan communist movement. Amin was firmly convinced that Parcham loyalists were the main obstacle to the success of the Revolution, and would lead a massive campaign of repression against anyone ever associated with the Parcham. ${ }^{21}$ As a result of this campaign, large amounts of anti-Soviet sentiment were rising not only in rural Afghanistan but also in urban centers, to the point that Soviet economic and political advisors were facing increasing threats of violence. $^{22}$

Throughout the summer, Moscow continued to back Taraki as the leader of the PDPA. Nonetheless, it was becoming increasingly apparent that Amin had successfully isolated Taraki by building a loyal support base within the military. On September 1, a KGB memo recommended the removal of Amin. ${ }^{23}$ On September 14, Amin would survive an assassination attempt by one of Taraki's security guards, most likely at the behest of the KGB itself. In response, Amin rapidly purged Taraki loyalists from the cabinet,

\footnotetext{
${ }^{20}$ Note: Amin would in fact hold numerous posts before assuming the leadership himself in late September 1979.

${ }^{21}$ Raymond L. Garthoff, Détente and Confrontation: American-Soviet Relations from Nixon to Reagan (Washington, D.C.: Brookings Institution Press, 1994), 1001-1014.

${ }^{22}$ Vasili Mitrokhin, The KGB in Afghanistan, 50.

${ }^{23}$ CPSU CC Politburo Decision, 15 September 1979. E-Dossier No. 4, 154.

Past Imperfect 12 [2006] | (C) | ISSN 1192-1315
} 
with Taraki himself being arrested. On September 16, Amin was 'elected' the General Secretary of the PDPA. Taraki was later executed on October 8 . It is during this period that proponents of a direct intervention gained influence within the Politburo: Arnold argues that "the Soviets must have decided that the time had come to do away with abortive coups and deception, and to handle 10 Afghanistan by the one invariably successful method they had employed elsewhere: outright military invasion."24

Upon Amin's coming to power, rumors quickly began to circulate within the Soviet establishment that Amin wished to distance himself from Moscow and move closer to the West. Amin had gradually begun removing pro-Soviet officials from sensitive positions and appointing Western-educated officials. ${ }^{25}$ In November, Amin's elder brother publicly stated that it would be wise to try to prod the West for possible incentives. ${ }^{26}$

While it is far from clear if Amin was actually initiating a shift towards the West - which the United States showed little interest in exploiting - or if he was simply trying to remove Moscow-loyalists whom he viewed as a threat to his rule, it is clear that the possibility of an independently minded communist state on the Soviet Union's southern border served as the major catalyst for invasion. KGB General and Andropov confident Leonid Shebarshin stated in a 1993 interview that the fear was that Amin was preparing to "[do] a Sadat on us." ${ }^{27}$ This fear, in less specific

\footnotetext{
${ }^{24}$ Arnold, The Fateful Pebble, 102.

${ }^{25}$ Kakar, Afghanistan, 42.

${ }^{26}$ Mitrokhin, The KGB in Afghanistan, 86.

${ }^{27}$ Note: This comment refers to Anwar Sadat, who famously steered Egypt, erstwhile considered one of Moscow's greatest foreign policy achievements, towards alignment with United States and the West during the late 1970s. Odd Arne Westad," "Concerning the situation in 'A': New Evidence on the Soviet Intervention in Afghanistan," in Documents on the Soviet Invasion of Afghanistan. E-Dossier No. 4. Cold War International History Project. Woodrow Wilson 
terms, was cited in a joint report by Gromyko, Ustinov, Ponomarev, and Andropov (The Afghanistan Commission) that was forwarded to the Politburo on October $29,1979 .{ }^{28}$ Although the report did not specifically recommend a direct intervention, a mission led by Deputy Defense Minister General Ivan Pavlovskii had already advised intervention in mid-August. ${ }^{29}$ With the despised Amin now firmly in power, the political leadership of the Soviet Union was now moving firmly towards direct intervention.

of the Politburo members, Andropov was undoubtedly the strongest proponent of intervention. It should be remembered that Andropov was one of the architects of the Hungarian invasion of 1956, and it has been suggested that he suffered from a "Hungarian Complex," feeling the need to stamp out 'ideological sabotage' wherever it reared its head. Andropov repeated this view at a KGB conference in 1979: "We simply do not have the right to permit even the smallest miscalculation here, for in the political sphere any kind of ideological sabotage is directly or indirectly intended to create an opposition which is hostile to our system ... and, in the final analysis, to create the conditions for the overthrow of socialism $^{30}$

While it appears as though the Politburo was officially shifting its policy towards intervention in November, there is strong evidence that both Andropov and Ustinov had begun preparations for an invasion earlier: in October, Ustinov had

International Center for Scholars, Washington, D.C. November 2001, 130. http://wilsoncenter.org/topics/pubs/e-dossier_4.pdf.

${ }^{28}$ Gromyko-Andropov-Ustinov-Ponomarev Report to CPSU CC, 29 OCTOBER 1979. E-Dossier No. 4, 157.

29 Mitrokhin, The KGB in Afghanistan, 11, and Christopher Andrew and Vasili Mitrokhin. The Mitrokhin Archive: The KGB in Europe and the West. New York: Penguin, 2000), 333-35.

${ }^{30}$ Andrew, Mitrokhin Archive II, 399. 
ordered Soviet units near the Afghan border to begin training for an invasion. ${ }^{31}$ Near the same time, Andropov had ordered meetings to be held with in the foreign services division of the KGB, which advised officers that upcoming events in Afghanistan would require the direct involvement of the KGB. In addition, on October 25, Lt. Col. A.V. Petrov of the KGB's Foreign Service division's 12) $8^{\text {th }}$ Directorate was sent to Prague to begin working with exiled Parcham leader Barbak Karmal. It appears that a government in exile was beginning to be formed at this time. ${ }^{32}$

The Andropov-Ustinov faction was also greatly assisted by other simultaneous developments on the world stage. Beijing's realignment towards Washington in the mid-1970s was a massive blow to the Soviet position, and thus should never have been underestimated in the strategic thinking of the Soviet leadership. Afghanistan was viewed as within China's area of interest. ${ }^{33}$ Even more recently, while the Soviet Union had made remarkable gains in the Middle East during the 1970s, most specifically the establishment of port facilities to permit Soviet naval operations in the Indian Ocean, Moscow was becoming increasingly worried about the region after Egypt's Anwar Sadat shifted politically towards the West. This is perhaps why Amin was compared to Sadat rather than to Yugoslavia's Tito, the standard insult of independently minded communist leaders.

One cannot underestimate the effects of the Iranian Revolution on both superpowers. Islamic radicalism emanating from Iran worried Moscow that Ayatollah Khomeini could forward

\footnotetext{
${ }^{31}$ Westad, "Concerning the situation in 'A", 130.

${ }^{32}$ Mitrokhin, The KGB in Afghanistan, 87.

${ }^{33}$ Zbigniew Brzezinksi, Power and Principle: Memoirs of the National Security Advisor, 1977-1981, (New York: Farrar, Straus, Giroux, 1983), 196-233, 403-25. 
his revolution to the Muslim Central Asian Soviet Republics. ${ }^{34}$ However, it was the grander notion that the United States, now ejected from Iran, would seek to relocate its facilities to Afghanistan, which carried greater weight. This was groundless, as the US showed little interest in Afghanistan both before and after the Iranian Revolution. ${ }^{35}$ Andropov suggested that US forces ejected from Iran would relocate to Afghanistan, despite the fact that US assets in Iran were limited to electronic listening posts and a few political and military advisors, a point Andropov undoubtedly knew yet did not reveal to his Politburo comrades. ${ }^{36}$

While the invasion of Afghanistan is often viewed as the final nail in Détente's coffin, relations between the United States and the USSR had deteriorated steadily prior to the invasion. In discussing the Afghan situation in early 1979, Foreign Minister Gromyko had stated that an intervention would unnecessarily jeopardize the major gains made by Détente, especially regarding the pending SALT II treaty, which heavily favored the Soviet Union. By the fall, it was clear SALT II was unlikely to be ratified by the US Senate. In addition, the Carter administration had begun diplomatic efforts among Western European leaders for the deployment of intermediate range nuclear forces (INF) in Western Europe to counter the earlier deployment of the mobile SS-20 IRBM

\footnotetext{
${ }^{34}$ Note: Interestingly, there is not mention of a fear of an Islamic resistance emerging in Afghanistan in the event of a Soviet occupation. Andrew, Mitrokhin Archive II, 389.

${ }^{35}$ Christian Fredrich, Ostermann, "Introduction," in New Evidence on the War in Afghanistan. Cold War International History Project Bulletin, Issue 14/15. Cold War International History Project. Woodrow Wilson International Center for Scholars, Washington, D.C. http://www.wilsoncenter.org/topics/pubs/c-afghanistan.pdf. 139.

${ }^{36}$ Alexei Vassiliev, Russian Policy in the Middle East: From Messianism to Pragmatism (London: Ithaca Press, 1993), 252.

Past Imperfect 12 [2006] | (C) | ISSN $1192-1315$
} 
in Eastern Europe. ${ }^{37}$ On December 2, two days following Bonn's agreeing to accept US Pershing II and cruise missiles, Andropov introduced the prospect that a Western-aligned Amin would allow the deployment of US nuclear missiles in Afghanistan, jeopardizing the safety of crucial strategic assets, including the massive ballistic missile fields of Kazakhstan. ${ }^{38}$ Andropov was clearly painting a 14| 'worst case' scenario for his Politburo comrades, including exploiting their own personal fears. Paradoxically, while Andropov believed the US was bold enough to deploy missiles in Afghanistan, he did not seem to believe that the US would react in any way to a large Soviet military incursion into Afghanistan.

While Andropov and Ustinov were largely in agreement on the need to intervene directly in Afghanistan, they initially disagreed about the nature of the intervention. Whereas, Andropov preferred a smaller KBG-led operation, Ustinov wished to see a much heavier military intervention. Within the Soviet armed forces, there was unquestionably a group that wished to test their military might. Russian journalist Alexei Vassiliev has said that there was a deeply held belief among many Soviet commanders that the Soviet troops needed to be tested in combat, as they were lagging two wars (Korea, Vietnam) behind the Americans. ${ }^{39}$ While there is no record of Ustinov being so blunt within official records, there is evidence that he intended to cycle units through Afghanistan so that as many units as possible could see some time of combat. ${ }^{40}$ Ustinov's views were no doubt bolstered by his

\footnotetext{
${ }^{37}$ Derek Leebaert, The Fifty-Year Wound: The True Price of America's Cold War Victory (New York: Little Brown, 2002), 481-86.

${ }^{38}$ Westad, "Concerning the situation in 'A"', 131.

${ }^{39}$ Vassiliev, Russian Policy in the Middle East, 253.

${ }^{40}$ Edgar O'Ballance, Afghan War 1839-1992: What Britain Gave Up and the Soviet Union Lost, (New York: Brassey's, 1993), 90.

Past Imperfect 12 [2006] | (C) | ISSN $1192-1315$
} 
successful proxy wars in the Horn of Africa, Angola, and Central America, and thus Andropov seemingly conceded this point.

In examining the months running up to the invasion, it is interesting to note that two figures are seemingly absent from the debate. Premier Kosygin, who in earlier months was the prime voice on Afghanistan, arguing strongly against intervention and resisting the introduction of Soviet troops into the country, did not participate in the latter debates on the subject. It is apparent that Kosygin was marginalized at some point during this period, as he did not even attend the December 12 Politburo meeting where the official decision to invade Afghanistan was made. This is reinforced by Kosygin's forced retirement soon thereafter in 1980.

Finally, from early on, General Secretary Leonid Brezhnev was absent in nearly all the decisions made on the issue. It is clear that Brezhnev is merely 'rubberstamping' whatever he is presented. For example, when Taraki arrived in Moscow to discuss the situation in Afghanistan, he first met with the full Politburo (minus Brezhnev), where actual decisions were made. Only later did Taraki meet with Brezhnev in a mere formality. ${ }^{41}$

Later, as the Soviet Union moved closer to invasion, the limited mental state of Brezhnev becomes even clearer. It is believed by many that Brezhnev was personally insulted by Amin's murdering of Taraki, whom he had met with on a number of occasions. ${ }^{42}$ In early December, Andropov sent Brezhnev a strongly worded memo, stressing that the Soviet Union was losing the gains of the 1978 Afghan revolution. ${ }^{43}$ It is believed that Andropov and

\footnotetext{
${ }^{41}$ Transcript: Conversation Brezhnev-Taraki, 20 March 1979. E-Dossier No. 4, 15-16.

${ }^{42}$ Vassiliev, Russian Policy in the Middle East, 257-58, 262.

${ }^{43}$ Douglas J. MacEachin, Predicting the Soviet Invasion of Afghanistan: The Intelligence Community's Record (Washington, D.C.: Center for the Study of Intelligence, Central Intelligence Agency, 2002), 40.

Past Imperfect 12 [2006] | (C) | ISSN 1192-1315
} 
Ustinov were given verbal approval by Brezhnev on December 8, four days before 'official' authorization was granted. The five-hundred-man Spetsnaz unit that would remove Amin was approved for deployment on December 6, six days before the official authorization. ${ }^{44}$ The actual events of December 12 are comical considering the massive implications for the Soviet Union.

16| Konstantin Chernenko, Brezhnev's loyal aid, presented a handwritten note titled "Concerning the Situation in 'A'," which was signed by Andropov, Ustinov, Gromyko, and Brezhnev. This meager document is the primary authorization for a war that contributed to the downfall of the Soviet Empire. ${ }^{45}$

\section{Conclusion}

On December 25, 1979, the Soviet Union invaded Afghanistan and removed Hafizullah Amin through force, replacing him with Parcham leader Babrak Karmal. For the next decade, the Soviet Union would struggle to tame Afghanistan. Who is to blame for this catastrophic disaster? Andropov was clearly the largest advocate of the invasion. When the invasion was authorized, it was highly unlikely that anyone knew more about the situation than Andropov. Andropov painted a picture in which the fate of the Soviet Union itself was at stake if success was not achieved in Afghanistan. He exploited even the minutest contingencies to instill fear. Yet Andropov was hardly alone in such analysis. Throughout the Cold War, there were individuals in both the Soviet Union and the United States who engaged in such 'zero sum' games, in which any loss was immediately to the benefit of your

\footnotetext{
${ }^{44}$ E-Dossier No. 4, 75.

${ }^{45}$ Westad, "Concerning the situation in 'A", 131. 
opponent. Former KGB General Oleg Kalugin has since said that the common view amongst the KGB, and with Andropov himself, was that "Afghanistan [was] as a country within our sphere of interest, and we thought we had to do whatever possible to prevent the Americans and the CIA from installing an anti-Soviet regime there." ${ }^{\prime 6}$ It was this mindset that allowed the Soviet Union to lose so much over a country that was worth so little strategically.

The decision to invade Afghanistan can also be viewed as an indictment on the Soviet leadership system: lifetime appointments do not ensure that the most able minds are in positions of power. Andropov and those who promoted intervention benefited from the leadership vacuum created by a decrepit and mentally incompetent leader. During the later Brezhnev years, it is apparent that senior leaders developed mini-fiefdoms within the Party. ${ }^{47}$ It was this period of uncertainty in leadership that allowed Andropov to limit the decision making process to himself and his supporters.

\section{Bibliography}

Andrew, Christopher, and Gordievsky, Christopher. KGB: The Inside Story of its Foreign Operations from Lenin to Gorbachev. London: Sceptre, 1991.

Andrew, Christopher, and Mitrokhin, Vasili. The Mitrokhin Archive: The KGB in Europe and the West. New York: Penguin, 2000.

Andrew, Christopher, and Mitrokhin, Vasili. The Mitrokhin Archive II: The KGB in the World. London: Allen Lane, 2005.

\footnotetext{
${ }^{46}$ Oleg Kalugin, Spymaster: My 32 Years in Intelligence and Espionage Against the West (London: Smith Gryphon, 1994), 233.

${ }^{47}$ Philip Roeder sees periods of high competition, as when a secessionist struggle within the CPSU was imminent, as bringing about inconsistent and high risk policies. See Philip G. Roeder, "Soviet Policies and Kremlin Politics," International Studies Quarterly 28 (1984), 171-93.
}

Past Imperfect 12 [2006] | (C) | ISSN 1192-1315 
Arnold, Anthony. The Fateful Pebble: The Soviet Invasion in Perspective. Novato, CA: Presidio Press, 1993.

Bradsher, Henry S. Afghan Communism and Soviet Intervention. Oxford: Oxford University Press, 1999.

Brzezinksi, Zbigniew. Power and Principle: Memoirs of the National Security Advisor, 1977-1981. New York: Farrar, Straus, Giroux, 1983.

Cold War International History Product. Documents on the Soviet Invasion of Afghanistan. E-Dossier No. 4. Cold War International History Project. Woodrow Wilson International Center for Scholars, Washington, D.C. November 2001. 13132. http://wilsoncenter.org/topics/pubs/e-dossier_4.pdf.

Coll, Steve. Ghost Wars: The Secret History of the CIA, Afghanistan, and bin Laden, from the Soviet Invasion to September 10, 2001. New York: Penguin Press, 2004.

Dupree, Louis, “Afghanistan Under the Khalq," Problems of Communism 28, no. 4 (1979), 34-50.

Garthoff, Raymond L. Détente and Confrontation: American-Soviet Relations from Nixon to Reagan. Washington, D.C.: Brookings Institution Press, 1994.

Gibbs, David, "Does the USSR Have a 'Grand Strategy'? Reinterpreting the Invasion of Afghanistan,” Journal of Peace Research 24, no. 4 (Dec. 1987), 365-379.

Giustozzi, Antonio. War, Politics and Soviet Society: 1978-1992. Washington, D.C.: Georgetown University Press, 2000.

Goldman, Milton F., "Soviet Military Intervention in Afghanistan: Roots and Causes," Polity 16, no. 3 (Spring 1984), 383-403.

Herrmann, Richard K. Perceptions and Behavior in Soviet Policy. Pittsburg, PA: University of Pittsburg Press, 1985.

Kakar, M. Hassan. Afghanistan: The Soviet Invasion and the Afghan Response, 1979-1982. Berkeley, CA: University of California Press, 1995.

Kalugin, Oleg. Spymaster: My 32 Years in Intelligence and Espionage Against the West. London: Smith Gryphon, 1994.

Leebaert, Derek. The Fifty-Year Wound: The True Price of America's Cold War Victory. New York: Little Brown, 2002.

Past Imperfect 12 [2006] | (C) ISSN 1192-1315 
MacEachin, Douglas J. Predicting the Soviet Invasion of Afghanistan: The Intelligence Community's Record. Washington, D.C.: Center for the Study of Intelligence, Central Intelligence Agency, 2002.

Mitrokhin, Vasili. The KGB in Afghanistan. Working Paper No. 40. Introduced and edited by Christian F. Ostermann and Odd Arne Westad. Cold War International History Project. Woodrow Wilson International Center for Scholars, Washington, D.C. Feb. 2002. http://wilsoncenter.org/topics/pubs/ACFAE9.pdf.

O’Ballance, Edgar. Afghan War 1839-1992: What Britain Gave Up and the Soviet Union Lost. New York: Brassey's, 1993.

Ostermann, Christian Fredrich, "Introduction," in New Evidence on the War in Afghanistan. Cold War International History Project Bulletin, Issue 14/15. Cold War International History Project. Woodrow Wilson International Center for Scholars, Washington, D.C. 139-41. http://www.wilsoncenter.org/topics/pubs/cafghanistan.pdf.

Payind, Alam, "Soviet-Afghan Relations from Cooperation to Occupation," International Journal of Middle East Studies 21, no. 1 (Feb. 1989), 107-128.

Roeder, Philip G, “Soviet Policies and Kremlin Politics," International Studies Quarterly 28 (1984), 171-93.

Snyder, Jack. Myths of Empire. Ithaca, NY: Cornell University Press, 1991.

Vassiliev, Alexei. Russian Policy in the Middle East: From Messianism to Pragmatism. London: Ithaca Press, 1993.

Westad, Odd Arne, "Concerning the situation in 'A': New Evidence on the Soviet Intervention in Afghanistan," in Documents on the Soviet Invasion of Afghanistan. EDossier No. 4. Cold War International History Project. Woodrow Wilson International Center for Scholars, Washington, D.C. November 2001. 131-32. http://wilsoncenter.org/topics/pubs/e-dossier_4.pdf. 